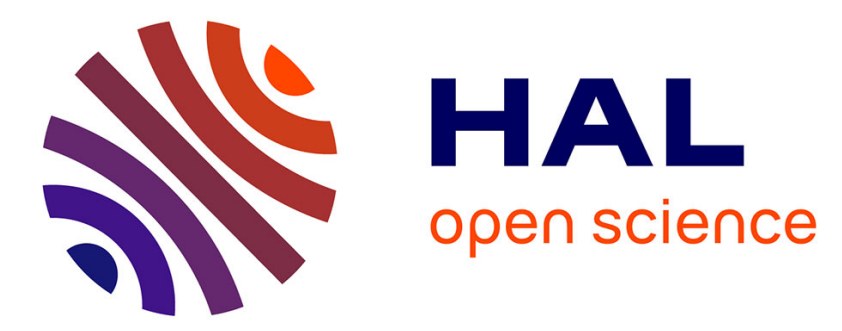

\title{
Ion-Selective Electrodes Based on p-tert-Butyl-homooxacalixarene di(ethyl)amides
}

Maria Krystyna Bocheńska, Peter J. Cragg, Marcin Guziński, Artur Jasinski, Joanna Kulesza, Paula Maria Marcos, Radoslaw Pomecko

\section{- To cite this version:}

Maria Krystyna Bocheńska, Peter J. Cragg, Marcin Guziński, Artur Jasinski, Joanna Kulesza, et al.. Ion-Selective Electrodes Based on p-tert-Butyl-homooxacalixarene di(ethyl)amides. Supramolecular Chemistry, 2009, 21 (08), pp.732-737. 10.1080/10610270902853043 . hal-00528956

\section{HAL Id: hal-00528956 https://hal.science/hal-00528956}

Submitted on 23 Oct 2010

HAL is a multi-disciplinary open access archive for the deposit and dissemination of scientific research documents, whether they are published or not. The documents may come from teaching and research institutions in France or abroad, or from public or private research centers.
L'archive ouverte pluridisciplinaire HAL, est destinée au dépôt et à la diffusion de documents scientifiques de niveau recherche, publiés ou non, émanant des établissements d'enseignement et de recherche français ou étrangers, des laboratoires publics ou privés. 


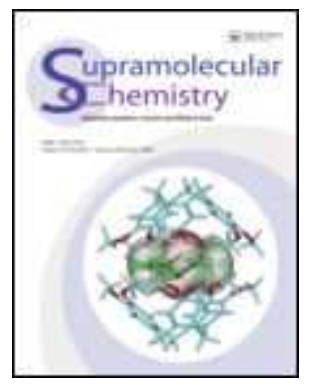

\section{Ion-Selective Electrodes Based on p-tert-Butyl-homooxacalixarene di(ethyl)amides}

\begin{tabular}{|r|l|}
\hline Journal: & Supramolecular Chemistry \\
\hline Manuscript ID: & GSCH-2009-0006.R1 \\
\hline Manuscript Type: & Full Paper \\
\hline Author: & 12 -Feb-2009 \\
\hline Complete List of Authors: & $\begin{array}{l}\text { Bocheńska, Maria; Gdañsk University of Technology, of Chemical } \\
\text { Technology } \\
\text { Cragg, Peter; University of Brighton, Pharmacy and Biomolecular } \\
\text { Sciencecs } \\
\text { Guziński, Marcin; Gdañsk University of Technology, of Chemical } \\
\text { Technology } \\
\text { Jasinski, Artur; Gdansk University of Technology, Chemical } \\
\text { Technology } \\
\text { Kulesza, Joanna; Gdansk University of Technology, Chemical } \\
\text { Technology } \\
\text { Marcos, Paula; Universidade de Lisboa, Chemistry Department } \\
\text { Pomecko, Radosław; Gdansk University of Technology, Chemical } \\
\text { Technology }\end{array}$ \\
\hline Keywords: & $\begin{array}{l}\text { Homooxacalixarenes, Amide derivatives, Ion-selective electrodes } \\
\text { (ISE),, Pb(II) ionophores, X-ray crystallographic structure }\end{array}$ \\
\hline
\end{tabular}

\section{S scholarONE" \\ Manuscript Central}


Maria Bocheńska, Peter J. Cragg, Marcin Guziński, Artur Jasiński, Joanna Kulesza, Paula M. Marcos and Radosław Pomećko

\section{Ion-Selective Electrodes Based}

on

p-tert-Butyl-homooxacalixarene di(ethyl)amides 


\section{Abstract}

The diethyl amides of p-tert-butyldihomooxacalix[4]arene (1), p-tert-butylhexahomotrioxacalix[3]arene (2) and p-tert-butylcalix[4]arene (3) were used as active materials in ion-selective membrane electrodes (ISE) to check the detection of different kinds of cations $\left(\mathrm{Na}^{+}, \mathrm{K}^{+}, \mathrm{Cs}^{+}\right.$, $\mathrm{Mg}^{2+}, \mathrm{Ca}^{2+}, \mathrm{Mn}^{2+}, \mathrm{Cu}^{2+}, \mathrm{Zn}^{2+}, \mathrm{Cd}^{2+}, \mathrm{Pb}^{2+}$ and $\left.\mathrm{TMA}^{+}\right)$. The electrode characteristics and selectivity coefficients were determined and compared. Optimisation of the PVC membrane composition was achieved using three different plasticizers (DEHA, $o$-NPOE or BBPA). Amide $\mathbf{3}$ shows selectivity for $\mathrm{Na}^{+}$, whereas compounds $\mathbf{1}$ and $\mathbf{2}$ exhibit the highest selectivity for $\mathrm{Pb}^{2+}$ among all the studied cations. The X-ray crystal structure of dihomooxacalix[4]arene tetra(diethyl)amide 1 was determined revealing it to be in the cone conformation.

Keywords: Calix[4]arene, Homooxacalixarenes, Amide derivatives, Ion-selective electrodes (ISE), $\mathrm{Pb}$ (II) ionophores, X-ray crystallographic structure

\section{Introduction}

Over the past three decades research in calixarene chemistry has been investigated with considerable amount of details [1,2]. The successes in calixarene research are mainly due to their relatively easy functionalization on both upper and lower rims to give a large variety of derivatives.

In the field of host-guest chemistry, chemical sensors $[3,4]$ are without doubt one of the most developed applications of the calixarene molecules. In particular, the use of neutral ionophores containing carbonyl groups at the lower rim for preparing ion-selective electrodes (ISEs) has been largely investigated, since the initial work of Diamond and McKervey [5]. Among these ionophores, functionalized calixarenes with ester groups have been the most tested, but studies with ketone and amide groups have also been performed. Due to the biological importance of ions such as $\mathrm{Na}^{+}, \mathrm{K}^{+}, \mathrm{Mg}^{2+}$ and $\mathrm{Ca}^{2+}$, those studies have been mainly focused on these kinds of cations, although ion-selective electrodes for cations other than the alkali and alkaline earth, such as transition and heavy metal cations, have also been assessed. The harmful 
impact that toxic metal ions such as cadmium, mercury and lead can provoke on environmental quality and consequently on human health, can explain the increasing interest in finding effective sensors for these metal ions. For example, the monitoring of lead in drinking water is important to ensure that its concentration remains below the acceptable level. This cation forms complexes with hard oxygen donor atoms as well as with nitrogen and sulphur that are considered to be softer bases. Thus, a variety of compounds have been tested so far as active materials for Pb-ionselective electrodes.

Following our previous studies on ion-selective electrodes based on calix[4]arene amide derivatives [6, 7] we have now extended them to homooxacalixarenes [8], namely dihomooxacalix[4]arene and hexahomotrioxacalix[3]arene amide derivatives [9, 10]. These are calixarene analogues in which one or all of the $\mathrm{CH}_{2}$ bridges have been replaced by $\mathrm{CH}_{2} \mathrm{OCH}_{2}$ groups. They are more flexible molecules than calix[4]arenes, but can still possess a cone conformation, the most appropriate for complexation, being potential hosts for the larger cations, mainly the dihomooxacalix[4]arene derivatives.

In this paper the performance of $p$-tert-butyldihomooxacalix[4]arene tetra(diethyl)amide (1) and p-tert-butylhexahomotrioxacalix[3] arene tri(diethyl)amide (2) are tested as ion-selective membrane electrodes towards a large variety of cations, including alkali, alkaline earth, transition and heavy metals, and using three different plasticizers (DEHA, o-NPOE or BBPA) in the membranes. The p-tert-butylcalix[4]arene tetra(diethyl)amide (3) was also studied in this work, and the results of the three derivatives (Fig. 1) are compared and discussed in terms of size and conformational effects. The X-ray crystal structure of dihomooxacalix[4]arene tetraamide $\mathbf{1}$ was determined.

\section{Results and discussion}

X-ray structure determination

The X-ray single crystal structural analysis revealed that dihomooxacalix[4]arene (diethyl)amide 1 adopts a pinched cone conformation with the tert-butyl groups pitched away from the cavity (Fig. 2). The conformation of compound 1 was analyzed by calculation of the dihedral angles between the phenyl rings A, B, C, D [11]. Rings A and C are almost parallel to each other (dihedral angle is only $5.15(18)^{\circ}$ ), whereas the rings $\mathrm{B}$ and $\mathrm{D}$ are almost perpendicular 
$\left(75.75(9)^{\circ}\right)$. Notably, the angle is much less than the commonly observed value of $90^{\circ}$ for regular calix[4]arenes. The presence of the oxygen bridge (O9) is the most probable cause of this deformation. Hydrogen bonds or interactions with the solvent molecules are not observed.

Attempts to obtain crystals of the complexes metal-ligand, especially with lead, were unsuccessful.

\section{Potentiometric Studies - ISE}

The ionophoric properties of di(ethyl)amides $\mathbf{1}, \mathbf{2}$ and $\mathbf{3}$ were studied by using them in ionselective membrane electrodes (ISE). All these compounds had been synthesised according to the literature and obtained in a cone conformation $[12,13,14]$. Due to the high lipophilicity of the macrocyclic ligands possessing four (1 and 3) or three (2) tert-butyl groups, all the electrodes prepared were stable and long lasting. The potentiometric responses of these ISEs towards a variety of ions, including alkali $\left(\mathrm{Na}^{+}, \mathrm{K}^{+}\right.$and $\left.\mathrm{Cs}^{+}\right)$, alkaline earth $\left(\mathrm{Mg}^{2+}\right.$ and $\left.\mathrm{Ca}^{2+}\right)$, transition $\left(\mathrm{Mn}^{2+}, \mathrm{Cu}^{2+}, \mathrm{Zn}^{2+}\right)$ and heavy metals $\left(\mathrm{Cd}^{2+}\right.$ and $\left.\mathrm{Pb}^{2+}\right)$, were measured. Among these cations with varying sizes, charges and nature, the strongest response was induced by the presence of $\mathrm{Na}^{+}, \mathrm{K}^{+}$ and $\mathrm{Pb}^{2+}$. This behaviour was expected, as the homooxa ligands are strong binders for those cations [9, 10], and it is known the high selectivity of calix[4]arene amides, like derivative $\mathbf{3}$, for $\mathrm{Na}^{+}[15]$.

The electrode membrane was optimized using three different plasticizers: bis(2ethylhexyl) adipate (DEHA), bis(2-butylpentyl) adipate (BBPA) and $o$-nitrophenyl octyl ether (NPOE). DEHA has a similar structure to BBPA, which in many cases is a good plasticizer for $\mathrm{Na}^{+}$-selective membrane electrodes (enhancing the $\mathrm{Na}^{+}$-response), whereas the $\mathrm{Pb}^{2+}$ cation usually prefers a more polar plasticizer such as NPOE. The membrane compositions and the characteristics of the electrodes are presented in Table 1 and illustrated in Figures 3 and 4.

In the case of homooxa di(ethyl)amides $\mathbf{1}$ and $\mathbf{2}$, the data (Table 1) reveal that the use of DEHA as plasticizers gives the best results relative to both mono and divalent cations, as the slopes of the electrode responses are close to the Nernstian values $\left(59.15\right.$ and $29.58 \mathrm{mV}$ decade $^{-1}$, respectively). Comparison between the three calixarene based electrodes shows that homooxacalixarenes $\mathbf{1}$ and $\mathbf{2}$ exhibit the best behaviour for $\mathrm{Pb}^{2+}$, while calix[4] arene amide $\mathbf{3}$ shows a preference for $\mathrm{Na}^{+}$cations. 
Potentiometric selectivities for the electrodes based on ionophores $\mathbf{1}, \mathbf{2}$ and $\mathbf{3}$ in all membranes were determined by the Separate Solution Method (SSM) [16]. The selectivity coefficients expressed as $\log K_{\mathrm{M}, \mathrm{X}}^{\mathrm{pot}}$ are presented in diagram form in Fig. 5. The selectivity coefficients for compound $\mathbf{1}$ are the best in PVC/NPOE membrane $\left(\log \mathrm{K}_{\mathrm{Pb}, \mathrm{Na}}^{\mathrm{pot}}=-2.5\right)$. However, low upper detection limit (narrow linear range) and anionic response of this electrode (Table 1) suggest strong interaction of ligand $\mathbf{1} \mathrm{Pb}(\mathrm{II})$ cation. The case of compound 2 is different. The selectivity coefficient for $\mathrm{Pb} / \mathrm{Na}$ in less polar plasticizer are better $\left(\log \mathrm{K}_{\mathrm{Pb}, \mathrm{Na}}^{\mathrm{pot}}=-\right.$ 1.5) than in PVC/NPOE membrane $\left(\log \mathrm{K}_{\mathrm{Pb}, \mathrm{Na}}^{\mathrm{pot}}=-0.3\right)$. The analogous amide 3 , based on classical calix[4]arene is definitely sodium selective with selectivity coefficient $\log \mathrm{K}_{\mathrm{Na}, \mathrm{Pb}}^{\mathrm{pot}}=-$ 3.3 .

Potentiometric selectivity coefficients reflect the ion-ligand complex formation constants directly in the membrane. The selectivity coefficients obtained for the electrodes with PVC/BBPA membranes were used to determination those constants, using the simple method proposed by Pretsch [17]. The values obtained are shown in Table 2.

The equilibrium constants are related to the estimated concentration of the species in the organic membrane phase and to the ions' activities in the aqueous phase, so they are not proper thermodynamic parameters. Values in Table 2 show that the interactions of dihomooxacalix[4]arene amide $\mathbf{1}$ and of calix[4]arene amide $\mathbf{3}$ in PVC/BBPA membrane with $\mathrm{Na}^{+}$are of similar strength, whereas those with hexahomotrioxacalix[3]arene amide 2 are weaker. This is probably due to its higher conformational flexibility. The replacement of the methylene bridges by dimethyleneoxa bridges in triamide 2 increases its flexibility. The $\Delta G^{\neq}$barriers for conformational inversion in $\mathrm{CDCl}_{3}$ are $<9,12.9$ and $15.7 \mathrm{kcal} \mathrm{mol}^{-1}$ for the corresponding parent calixarenes of $\mathbf{2}, \mathbf{1}$ and $\mathbf{3}$, respectively [18]. Moreover, $\mathbf{2}$ possesses only three amide groups and consequently only six coordination sites are available to surround the cations, compared to the eight sites of the tetraamides. In the case of $\mathrm{K}^{+}$interactions, amide $\mathbf{1}$ exhibits the highest constant value, reflecting its larger cavity size, more suitable to accommodate a larger cation. These constants determined in the membrane for ligands $\mathbf{1}$ and $\mathbf{3}$, although lower, follow the same selectivity trend observed in the 1:1 stability constants previously determined in methanol [9]. In the case of $\mathrm{Pb}^{2+}$, triamide $\mathbf{2}$ shows the highest constant value closely followed by tetraamide $\mathbf{1}$, whereas for $\mathbf{3}$ that value is approximately $2.5 \log$ units lower. It seems that more important than the number of donating sites, it should be the conformational rearrangement that the pendant 
arms of the ligands can suffer upon complexation, to better accommodate that cation. However, it is worthwhile pointing out that the coordination number of $\mathrm{Pb}^{2+}$ is 6 [19]. Thus, three phenolic oxygen atoms and three carbonyl oxygen atoms should suffice for inclusion of that cation.

The fact that plasticizers of different nature i.e. ether (NPOE) and ester (DEHA, BBPA) induce different $\mathrm{Pb}^{2+}$-selectivity in homooxacalixarene amides $\mathbf{1}$ and $\mathbf{2}$ seems to suggest different coordination types occur in the two membranes. The selectivity $\mathrm{Pb}^{2+} / \mathrm{Na}^{+}$of ligand $\mathbf{1}$ is better in NPOE than in DEHA, which has also been observed for other calix[4]arenes. This suggests that in ligand $\mathbf{1}$ the $\mathrm{Pb}^{2+}$ cation is complexed by the same type of oxygen atoms as in calix[4]arene $\mathbf{3}$, i.e. phenoxy and carbonyl oxygen atoms. By contrast, the selectivity $\mathrm{Pb}^{2+} / \mathrm{Na}^{+}$by ligand 2 in NPOE is worse than in DEHA, which might suggest that $\mathrm{Pb}^{2+}$ cation is complexed in a different part of the compound. Nevertheless, results previously obtained either by NMR or by molecular mechanics / ab initio techniques for ligand 2 [10] and also with an analogous derivative [20], indicate that the oxygen atoms of the $\mathrm{ArCH}_{2} \mathrm{OCH}_{2} \mathrm{Ar}$ bridges do not participate in metal binding.

\section{Conclusions}

The performance of the ion-selective electrodes based on homooxacalixarene amides $\mathbf{1}$ and $\mathbf{2}$ and on calix[4]arene amide $\mathbf{3}$ indicated a high affinity of the homooxa ligands for the heavy metal cation $\mathrm{Pb}^{2+}$, whereas calix[4] arene 3 showed selectivity for $\mathrm{Na}^{+}$. From the comparison between the three plasticizers (DEHA, $o$-NPOE and BBPA) used in the PVC-membrane, it is clear that their role is not negligible.

The X-ray diffraction studies revealed a cone conformation for dihomooxacalix[4]arene tetra(diethyl)amide 1, confirming that all three amides exist in the same conformer in the electrode membranes.

\section{Experimental \\ Crystallography}


Compound 1 (15 mg) was dissolved in the minimal amount of methylene chloride and treated with $1 \mathrm{~mL}$ of methanol. After several days transparent crystals, suitable for crystallography, were obtained.

The structure of $\mathbf{1}$ was determined by single crystal X-ray diffraction. The data were collected at $120 \mathrm{~K}$ on a KM4CCD diffractometer equipped with a Sapphire $2 \mathrm{CCD}$ detector. Enhanced X-ray Mo- $\mathrm{K}_{\alpha}$ radiation source with a graphite monochromator was used. The preliminary calculations were done using CrysAlis software package [11]. The structure was solved by direct methods and all non-hydrogen atoms were refined with anisotropic displacement parameters by full-matrix least squares procedure based on $F^{2}$. All hydrogen atoms were refined using isotropic model with $\mathrm{U}_{\text {iso }}$ values fixed to be 1.5 times $\mathrm{U}_{\text {eq }}$ of $\mathrm{C}$ atoms for $\mathrm{CH}_{3}$ or 1.2 times $\mathrm{U}_{\mathrm{eq}}$ for $\mathrm{CH}_{2}$ and $\mathrm{CH}$ groups. Refinement was carried out using SHELXL-97 program package [21]. Ethyl group bound to N4 (labeled C63-C64) was refined as disordered over two positions with probabilities of $0.521(12) / 0.479(12)$.

Crystal data and structure refinement details for compound $\mathbf{1}$ are presented in Table 3.

\section{Potentiometric studies}

\section{Membrane preparation and emf measurements}

The membranes were prepared by dissolving about $4 \mathrm{mg}$ of each ionophore, $60 \mathrm{mg}$ of PVC, $120 \mathrm{mg}$ of plasticizer (BBPA, DEHA or $o$-NPOE) and $0.4 \mathrm{mg}$ of KTpCIPB salt with a lipophilic anion, about $184 \mathrm{mg}$ in total, in $1.5 \mathrm{~mL}$ of dried and distilled THF. Each solution was poured into a glass ring (24 $\mathrm{mm}$ in diameter). After slow evaporation of the solvent overnight, several membranes of $7 \mathrm{~mm}$ diameter were cut from each mother membrane and were incorporated into $\mathrm{Ag} / \mathrm{AgCl}$ electrode bodies of IS 561 type (Moeller S.A., Zurich). A double-junction reference electrode (Radelkis 0P0820P) and $1 \mathrm{M} \mathrm{NH}_{4} \mathrm{NO}_{3}$ solution in the bridge cell were used. The EMFs were measured at $20{ }^{\circ} \mathrm{C}$ using a Lawson Lab 16 EMF, multi-channel voltmeter. The electrodes were conditioned in $10^{-4} \mathrm{M} \mathrm{HNO}_{3}$. The measurements were carried out in separate solutions of known cation concentrations starting from $10^{-8}$ to $10^{-1} \mathrm{M}$. $\mathrm{pH}=4$ was adjusted and stabilised by addition of $\mathrm{HNO}_{3}$. The measurements were carried using the cells of the type:

Ag|AgCll1 M KCll1 $\mathrm{M} \mathrm{NH}_{4} \mathrm{NO}_{3}$ I sample II membrane $\| 10^{-3} \mathrm{M} \mathrm{MgCl}_{2}, 10^{-4} \mathrm{M}_{\text {EDTAlAgCllAg }}$ 


\section{Determination of selectivity coefficients}

The potentiometric response of the electrodes for a series of cations was studied using chlorides or nitrates. The selectivity coefficients $\left(\log K^{\mathrm{pot}}{ }_{\mathrm{M}, \mathrm{X}}\right)$ were determined by the Separate Solution Method (SSM) and were calculated (equation 1) using the EMF values extrapolated from the characteristics of the electrodes studied to the cation $1 \mathrm{M}$ concentration [16]:

$$
\log K_{M, X}^{p o t}=\frac{\left(E_{X}-E_{M}\right) z_{M}^{F}}{2.303 R T}+\left(1-\frac{z_{M}}{z_{X}}\right) \log a_{X}
$$

In eq. $1, M$ and $X$ correspond to the primary and the interfering cations respectively, and $z_{M}$ and $z_{X}$ correspond to their charges.

\section{Determination of complex formation constants in the electrode membrane}

The values of the complex formation constants $(\log \beta)$ for ionophores $\mathbf{1}, \mathbf{2}$ and $\mathbf{3}$ in PVC/BBPA membranes were estimated by the method described by Pretsch et al. [17]. The composition of these membranes is given in Table 4. Tetramethylammonium cation $\left(\mathrm{TMA}^{+}\right)$was used as a reference ion. The calculation is based on the assumption that the ionophores form stable 1:1 complexes with metal ions such as $\mathrm{Na}^{+}, \mathrm{K}^{+}$and $\mathrm{Pb}^{+2}$. The values of the complex formation constants were calculated from the following equation:

$$
\beta=\frac{K_{M, T M A}^{p o t}(I E)}{K_{M, T M A}^{p o t}(L)\left[L_{T}-R_{T}\right]}
$$

where $L_{\mathrm{T}}$ is the total concentration of the ionophore within the membrane, $R_{\mathrm{T}}$ the total concentration of the lipophilic anionic site (KTpClPB) in the membrane, $K^{\mathrm{pot}}{ }_{\mathrm{M}, \mathrm{TMA}}$ (IE) the selectivity coefficient for the membrane without ionophore, $K^{\mathrm{pot}}$ M,TMA (L) the selectivity coefficient for the membrane with ionophore $(\mathrm{L})$ and $\mathrm{M}=\mathrm{Na}^{+}, \mathrm{K}^{+}$and $\mathrm{Pb}^{2+}$. 


\section{Supplementary material available}

Crystallographic data for the structure $\mathbf{1}$ reported in this paper have been deposited with the Cambridge Crystallographic Data Centre as supplementary publication No. CCDC 702250

\section{Acknowledgements}

Financial support from the Polish Ministry of Higher Education and Science, grant No N N204 274235, is gratefully acknowledged. We also thank Dr J. Chojnacki from Gdańsk University of Technology for X-ray crystal structure determination.

\section{References}

(1) Gutsche, C. D. In Calixarenes Revisited; Stoddart, J. F., Ed.; The Royal Society of Chemistry: Cambridge, 1998.

(2) Calixarenes 2001; Asfari, Z.; Böhmer, V.; Harrofield, J.; Vicens, J., Eds.; Kluwer Academic: Dordrecht, 2001.

(3) Diamond, D.; McKervey, M. A. Chem. Soc. Rev. 1996, 15-24.

(4) Cadogan, F.; Nolan, K.; Diamond, D. In Calixarenes 2001; Asfari, Z.; Böhmer, V.; Harrofield, J.; Vicens, J., Eds.; Kluwer Academic: Dordrecht, 2001; pp 627-641.

(5) Diamond, D.; Svehla, G.; Seward, E. M.; McKervey, M. A. Anal. Chim. Acta 1988, 204, 223231.

(6) Bochenska, M.; Banach, R.; Zielinska, A.; Kravtsov, V. J. Incl. Phenom. Macrocyclic Chem. 2001, 39, 219-228.

(7) Bochenska, M.; Lesinska, U. Chem. Anal. 2006, 51, 879-887.

(8) Masci, B. In Calixarenes 2001; Asfari, Z.; Böhmer, V.; Harrofield, J.; Vicens, J., Eds.; Kluwer Academic: Dordrecht, 2001; pp 235-249.

(9) Marcos, P. M.; Félix, S.; Ascenso, J. R.; Segurado, M. A. P.; Pereira, J. L. C.; Khazaeli-Parsa, P.; Hubscher-Bruder, V.; Arnaud-Neu, F. New J. Chem. 2004, 28, 748-755.

(10) Marcos, P. M.; Ascenso, J. R.; Cragg, P. J. Supramol. Chem. 2007, 19, 199-206. 
(11) Oxford Diffraction, CrysAlis CCD and CrysAlis RED, Version 1.171 Oxford Diffraction Ltd. Abington, Oxfordshire, England, 2005.

(12) Félix, S.; Ascenso, J. R.; Lamartine, R.; Pereira, J. L. C. Tetrahedron 1999, 55, 8539-8546.

(13) (a) Matsumoto, T.; Nishio, S.; Takeshita, M.; Shinkai, S. Tetrahedron 1995, 51, 4647-4654.

(b) Cragg, P. J.; Drew, M. G. B.; Steed, J. W. Supramol. Chem. 1999, 11, 5-15.

(14) (a) A. Arduini, E. Ghidini, A. Pochini, R. Ungaro, G. Andreetti, G. Calestani and F. Ugozzoli, J. Incl. Phenom. 1988, 6, 119-134. (b) Lesinska, U.; Bochenska, M. Synthesis 2006, $16,2671-2676$.

(15) Arnaud-Neu, F.; Barrett, G.; Fanni, S.; Marrs, D.; McGregor, W.; McKervey, M. A.; Schwing-Weill, M. J.; Vetrogon, V.; Wechsler, S. J. Chem. Soc., Perkin Trans. 2 1995, 453-461. (16) (a) Bakker, E.; Pretsch, E.; Buhlmann, P. Anal. Chem. 2000, 72, 1127-1133. (b) Umezawa, Y.; Buhlmann, P.; Umezawa, K.; Tohda, K.; Amemiya, S. Pure Appl. Chem. 2000, 72, 18512082.

(17) Ceresa, A.; Pretsch, E. Anal. Chim. Acta 1999, 395, 41-52.

(18) Gutsche, C. D.; Bauer, L. J. J. Am. Chem. Soc. 1985, 107, 6052-6059.

(19) Lee, J. D. In Concise Inorganic Chemistry; Wiley-Blackwell: Oxford, 1999.

(20) Marcos, P. M.; Ascenso, J. R.; Segurado, M. A. P.; Bernardino, R. J.; Cragg, P. J. Tetrahedron 2009, 65, 496-503.

(21) Sheldrick, G. M. Acta Cryst. 2008, A64, 112-122. 
Table 1 Characteristics of the electrodes

\begin{tabular}{|c|c|c|c|c|}
\hline Ionophore & Plasticizer & Detected Ion & Slope/mV decade ${ }^{-1}$ & Linear range $(-\log C)$ \\
\hline \multirow[t]{3}{*}{1} & DEHA & $\mathrm{Na}^{+}$ & 50.3 & $5-1$ \\
\hline & & $\mathrm{K}^{+}$ & 49.7 & $4.5-1$ \\
\hline & & $\mathrm{Pb}^{2+}$ & 28.8 & $5.5-2$ \\
\hline \multirow[t]{3}{*}{2} & DEHA & $\mathrm{Na}^{+}$ & 52.3 & $4.5-1$ \\
\hline & & $\mathrm{K}^{+}$ & 46.5 & $4-1$ \\
\hline & & $\mathrm{Pb}^{2+}$ & 30.5 & $6-2$ \\
\hline \multirow[t]{3}{*}{1} & NPOE & $\mathrm{Na}^{+}$ & 34 & $5.5-2$ \\
\hline & & $\mathrm{K}^{+}$ & 39.4 & $5-2$ \\
\hline & & $\mathrm{Pb}^{2+}$ & 37.4 & $6-4$ \\
\hline \multirow[t]{3}{*}{2} & NPOE & $\mathrm{Na}^{+}$ & 46.2 & $4.5-1$ \\
\hline & & $\mathrm{K}^{+}$ & 26.7 & $4-1$ \\
\hline & & $\mathrm{Pb}^{2+}$ & 31.4 & $5.5-2$ \\
\hline \multirow[t]{3}{*}{1} & BBPA & $\mathrm{Na}^{+}$ & 50.3 & $5-2$ \\
\hline & & $\mathrm{K}^{+}$ & 43.4 & $5-2$ \\
\hline & & $\mathrm{Pb}^{2+}$ & 39.6 & $5-3$ \\
\hline \multirow[t]{3}{*}{2} & BBPA & $\mathrm{Na}^{+}$ & 51.2 & $4-1$ \\
\hline & & $\mathrm{K}^{+}$ & 47.2 & $3-1$ \\
\hline & & $\mathrm{Pb}^{2+}$ & 51.3 & $6-1$ \\
\hline \multirow[t]{3}{*}{3} & BBPA & $\mathrm{Na}^{+}$ & 62.5 & $5-2$ \\
\hline & & $\mathrm{K}^{+}$ & 39.2 & $3-1$ \\
\hline & & $\mathrm{Pb}^{2+}$ & 35.4 & $4-1$ \\
\hline
\end{tabular}


Table 2. Complex formation constants $(\log \beta)^{\mathrm{a}}$

\begin{tabular}{cccc}
\hline Ionophore & $\mathrm{Na}^{+}$ & $\mathrm{K}^{+}$ & $\mathrm{Pb}^{2+}$ \\
\hline $\mathbf{1}$ & $5.51 \pm 0.08$ & $5.08 \pm 0.03$ & $7.93 \pm 0.05$ \\
$\mathbf{2}$ & $4.83 \pm 0.08$ & $3.80 \pm 0.05$ & $8.22 \pm 0.05$ \\
$\mathbf{3}$ & $5.52 \pm 0.04$ & $2.85 \pm 0.04$ & $5.58 \pm 0.02$ \\
\hline
\end{tabular}

${ }^{\text {a }}$ Standard deviation shown are from at least three replicate measurements 
Table 3. Crystal data and structure refinement details for $\mathbf{1}$

\begin{tabular}{|c|c|c|}
\hline Identification code & \multicolumn{2}{|l|}{1} \\
\hline Empirical formula & \multicolumn{2}{|l|}{ C69 H102 N4 O9 } \\
\hline Molecular weight & \multicolumn{2}{|l|}{1131.55} \\
\hline Temperature & \multicolumn{2}{|l|}{$120(2) \mathrm{K}$} \\
\hline Wavelength & \multicolumn{2}{|l|}{$0.71073 \AA$} \\
\hline Crystal system & \multicolumn{2}{|l|}{ Triclinic } \\
\hline Space group & \multicolumn{2}{|l|}{$\mathrm{P}-1$} \\
\hline \multirow[t]{3}{*}{ Unit cell dimensions } & $\mathrm{a}=10.9809(10) \AA$ & $\alpha=97.039(9)^{\circ}$. \\
\hline & $\mathrm{b}=13.7265(19) \AA$ & $\beta=94.628(7)^{\circ}$. \\
\hline & $c=22.678(2) \AA$ & $\gamma=100.731(10)^{\circ}$ \\
\hline Volume & \multicolumn{2}{|l|}{$3314.3(6) \AA^{3}$} \\
\hline $\mathrm{Z}$ & \multicolumn{2}{|l|}{2} \\
\hline Density (calculated) & \multicolumn{2}{|l|}{$1.134 \mathrm{Mg} / \mathrm{m}^{3}$} \\
\hline Absorption coefficient & \multicolumn{2}{|l|}{$0.074 \mathrm{~mm}^{-1}$} \\
\hline $\mathrm{F}(000)$ & \multicolumn{2}{|l|}{1232} \\
\hline Crystal size & \multicolumn{2}{|c|}{$0.41 \times 0.13 \times 0.12 \mathrm{~mm}^{3}$} \\
\hline Theta range for data collection & \multicolumn{2}{|l|}{2.36 to $25.50^{\circ}$. } \\
\hline Index ranges & \multicolumn{2}{|c|}{$-13<=\mathrm{h}<=13,-16<=\mathrm{k}<=12,-26<=1<=27$} \\
\hline Reflections collected & \multicolumn{2}{|l|}{24116} \\
\hline Independent reflections & \multicolumn{2}{|c|}{$12324[\mathrm{R}(\mathrm{int})=0.0540]$} \\
\hline Completeness to theta $=25.50^{\circ}$ & \multicolumn{2}{|l|}{$99.7 \%$} \\
\hline Absorption correction & \multicolumn{2}{|c|}{ Semi-empirical from equivalents } \\
\hline Max. and min. transmission & \multicolumn{2}{|l|}{1 and 0.97425} \\
\hline Refinement method & \multicolumn{2}{|c|}{ Full-matrix least-squares on $\mathrm{F}^{2}$} \\
\hline Data / restraints / parameters & \multicolumn{2}{|l|}{$12324 / 0 / 770$} \\
\hline Goodness-of-fit on $\mathrm{F}^{2}$ & \multicolumn{2}{|l|}{1.018} \\
\hline Final $\mathrm{R}$ indices [I>2sigma $(\mathrm{I})]$ & \multicolumn{2}{|c|}{$\mathrm{R} 1=0.0743, \mathrm{wR} 2=0.2015$} \\
\hline $\mathrm{R}$ indices (all data) & \multicolumn{2}{|c|}{$\mathrm{R} 1=0.1187, \mathrm{wR} 2=0.2283$} \\
\hline Largest diff. peak and hole & \multicolumn{2}{|c|}{0.759 and -0.313 e. $\AA^{-3}$} \\
\hline
\end{tabular}


Table 4 Composition of the PVC/BBPA membranes

\begin{tabular}{ccccc}
\hline & $\begin{array}{c}\mathrm{L}_{\mathrm{T}} \\
(\mathrm{mmol} / \mathrm{kg})\end{array}$ & $\begin{array}{c}\mathrm{R}_{\mathrm{T}} \\
\mathrm{KTClPB} \\
(\mathrm{mmol} / \mathrm{kg})\end{array}$ & BBPA (mg) & PVC (mg) \\
\hline Blank & 0 & 5.52 & 121.0 & 61.0 \\
$\mathbf{1}$ & 24.21 & 5.40 & 120.5 & 61.5 \\
$\mathbf{2}$ & 23.85 & 5.43 & 120.0 & 60.0 \\
$\mathbf{3}$ & 23.13 & 5.33 & 120.0 & 62.5 \\
\hline
\end{tabular}


Figure 1. Structural formula of the calixarenes studied.

Figure 2. Crystal structure of dihomooxacalix[4]arene tetra(diethyl)amide $\mathbf{1}$.

Figure 3. Electrode characteristics containing ligand 1 in a PVC/BBPA membrane.

Figure 4. Electrode characteristics containing ligand 2 in a PVC/BBPA membrane.

Figure 5. Potentiometric selectivity coefficients of ligands $\mathbf{1}, 2$ versus $\mathrm{Pb}^{2+}$ in PVC/DEHA and PVC/NPOE membrane $\left(\log \mathrm{K}_{\mathrm{Pb}, \mathrm{M}}^{\mathrm{pot}}\right)$ and of ligand 3 versus $\mathrm{Na}^{+}$in PVC/DEHA $\left(\log \mathrm{K}^{\mathrm{pot}}{ }_{\mathrm{Na}, \mathrm{M}}\right)$ for comparison. 


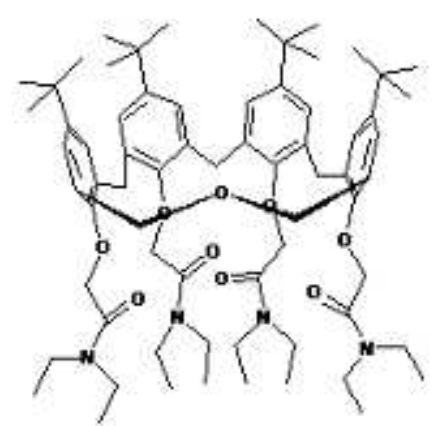

1

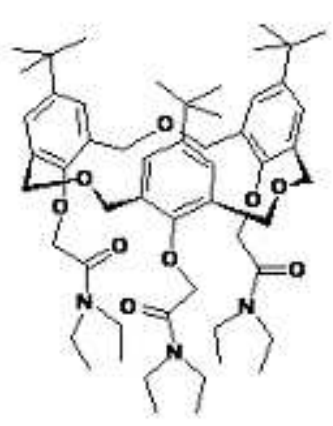

2

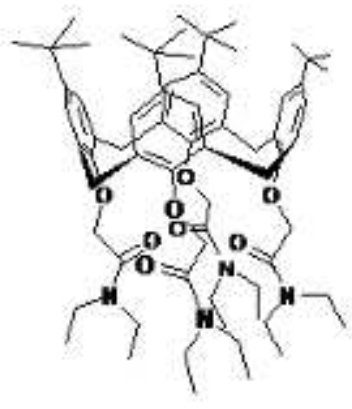

3

$172 \times 77 \mathrm{~mm}(72 \times 72 \mathrm{DPI})$ 


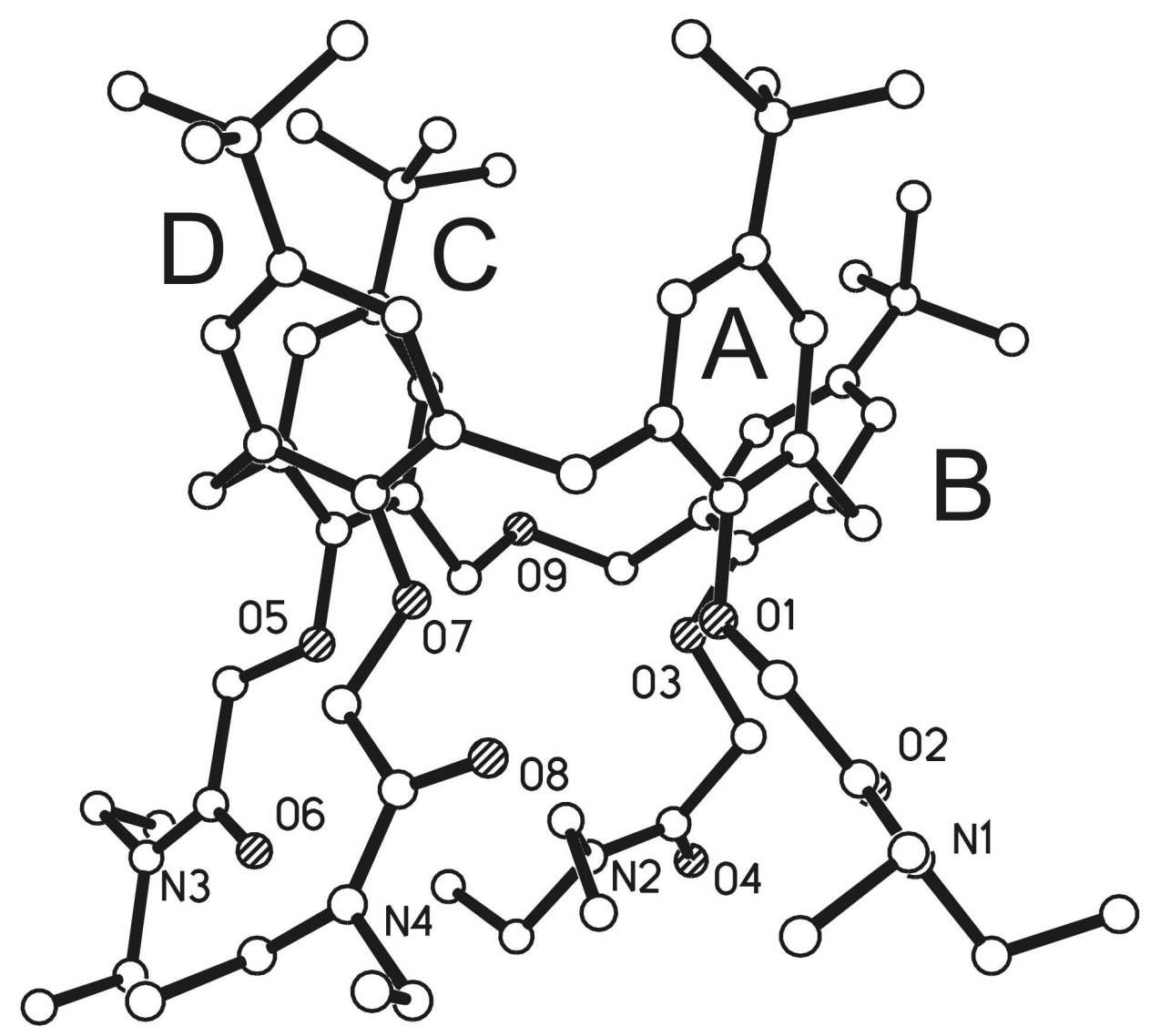

Figure 2. Crystal structure of dihomooxacalix[4]arene tetra(diethyl)amide 1. $84 \times 84 \mathrm{~mm}(600 \times 600 \mathrm{DPI})$ 
EMF [mV]

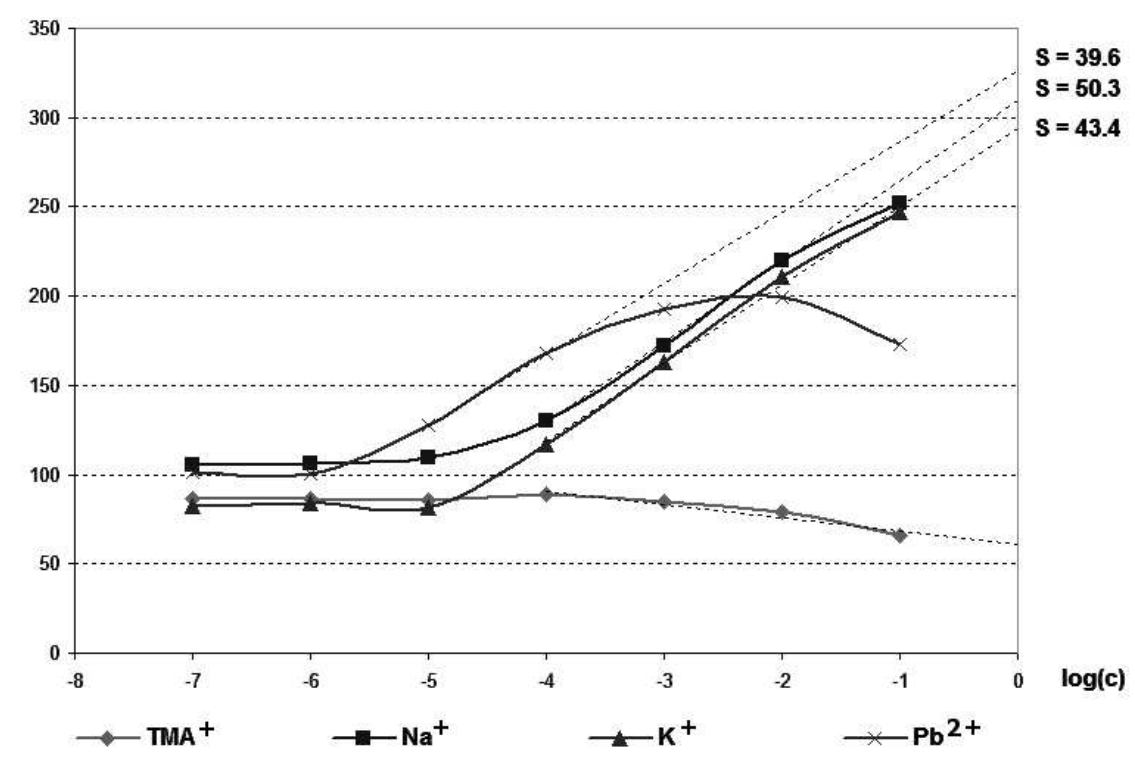

$312 \times 213 \mathrm{~mm}(72 \times 72 \mathrm{DPI})$ 
2

3

4

5

6

7

8

10

11

12

13

14

15

16

17

18

19

20

21

22

23

24

25

26

27

28

29

30

31

32

33

34

35

36

37

38

39

40

41

42

43

44

45

46

47

48

49

50

51

52

53

54

55

56

57

58

59

60

EMF [mV]

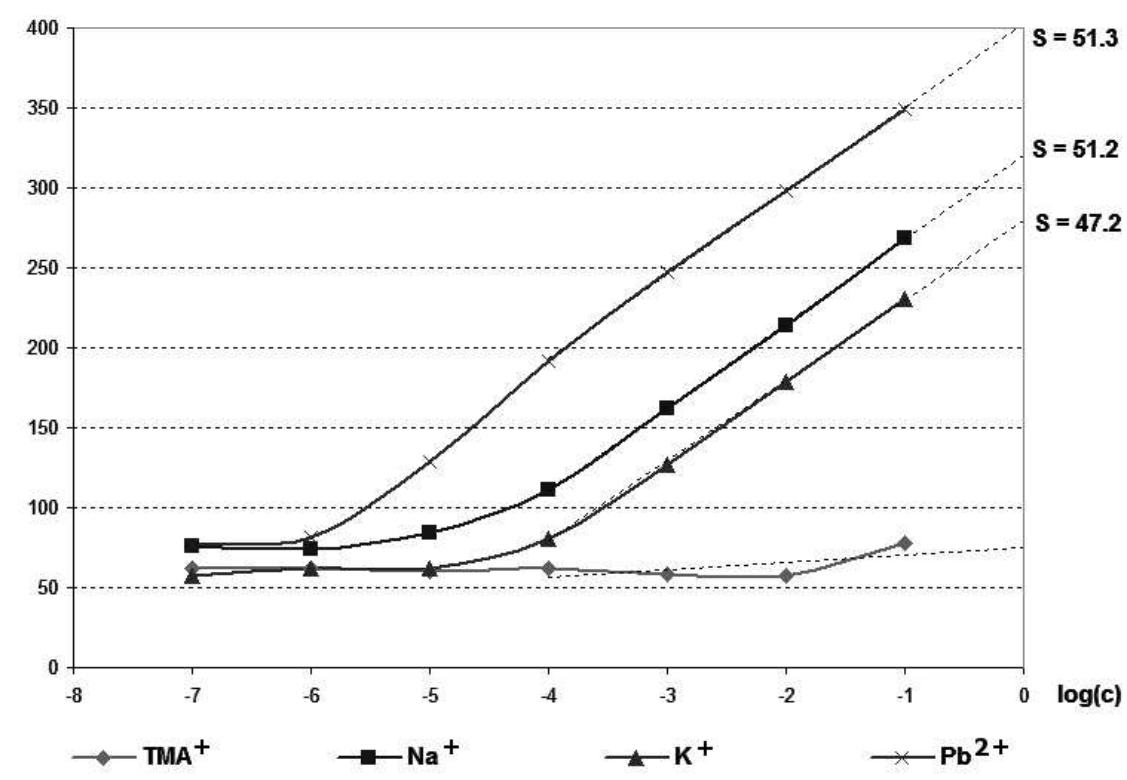

Figure 4. Electrode characteristics containing ligand 2 in a PVC/BBPA membrane. $310 \times 218 \mathrm{~mm}(72 \times 72$ DPI $)$

URL: http:/mc.manuscriptcentral.com/tandf/gsch Email: suprachem@mail.cm.utexas.edu 
Figure 5. Potentiometric selectivity coefficients of ligands 1,2 versus $\mathrm{Pb} 2+$ in PVC/DEHA and PVC/NPOE membrane (log KpotPb,M) and of ligand 3 versus $\mathrm{Na}+$ in PVC/DEHA (log KpotNa,M) for comparison. $342 \times 213 \mathrm{~mm}(72 \times 72 \mathrm{DPI})$

URL: http:/mc.manuscriptcentral.com/tandf/gsch Email: suprachem@mail.cm.utexas.edu 